\title{
Management of Black Spot of Rose with Winter Fungicide Treatment
}

\author{
K. L. Bowen, Professor, Department of Entomology and Plant Pathology, and R. S. Roark, Former Graduate As- \\ sistant, Department of Horticulture, Alabama Agricultural Experiment Station System, Auburn University 36849
}

\begin{abstract}
Bowen, K. L., and Roark, R. S. 2001. Management of black spot of rose with winter fungicide treatment. Plant Dis. 85:393-398.

Fungicides were evaluated for their efficacy against black spot of rose, caused by Diplocarpon rosae, when applied during winter months to hybrid tea rose plants in two studies. One study, conducted at two Auburn University campus sites, consisted of applications of horticultural oil, chlorothalonil plus an antitranspirant, and cyproconazole, along with nontreated plants; one site included triforine applications. Rose canes were treated two and three times between late October and February in 1996-97 and 1997-98, respectively; then plants were examined every 2 to 4 days beginning in mid-February for onset of symptoms of black spot. In both years, winter applications of fungicides (chlorothalonil, cyproconazole, and triforine) delayed disease onset compared with treatments without fungicides (nontreated and oil applications). Decreased plant defoliation, as well as improved plant vigor, were observed through the 1998 growing season following fungicidal winter treatments at campus sites; winter treatments with oil did not suppress disease compared with no treatment. In a second study started in November 1997, at a site near Shorter, AL, three systemic fungicides (myclobutanil, cyproconazole, and triforine) were applied to rose canes during the winter; nontreated plants were included. Decreased disease symptoms and defoliation of rose plants were observed early in the 1998 and 1999 seasons following winter applications of cyproconazole and triforine compared with myclobutanil or nontreated plants. Winter treatments with these fungicides did not consistently provide seasonlong reduction of black spot. However, season-long plant vigor and flower production on plants were improved at the Shorter site following winter applications of any of the above systemic fungicides compared with nontreated plants.
\end{abstract}

Black spot disease, caused by Diplocarpon rosae F.A. Wolf, is the most important disease of cultivated roses (Rosa spp.) in the southeastern United States (3,12). Once established on plants, black spot is difficult to control despite a combination of practices that include sanitation measures and fungicide applications (2). Sanitation measures that are recommended for managing black spot disease of rose include replacing mulch and removing and destroying fallen leaves (2).

Fungicides labeled for use on roses include lime-sulfur as a dormant spray, the protectant fungicides chlorothalonil and mancozeb, and the systemic fungicides myclobutanil and triforine (6). Generally, protectant fungicides must be applied to plants to protect against infection, while systemic fungicides are absorbed into plant tissue and can minimize disease symptoms after infection has occurred. Products that are readily available to rose hobbyists and homeowners in the United States currently include mancozeb (e.g., Fore Rainshield, Rohm \& Haas, Philadelphia, PA), my-

Corresponding author: Kira L. Bowen

E-mail: kbowen@acesag.auburn.edu

Accepted for publication 6 December 2000.

Publication no. D-2001-0122-01R

(C) 2001 The American Phytopathological Society clobutanil (e.g., Ortho's Immunox, Solaris Group, San Ramon, CA, and Eagle, Rohm \& Haas), and triforine (e.g., Ortho's Funginex). All of these products are labeled for application on 7- to 10-day intervals throughout the growing season for control of black spot of rose. In the southeastern United States, with a growing season of 6 months or more, 20 or more fungicide applications may be needed to maintain disease-free rose plants.

In studies conducted by Hagan et al. $(10,11)$, chlorothalonil applications on 2week intervals provided better control of black spot than did the systemic fungicide triforine and the ergosterol biosynthesisinhibiting (EBI) fungicides myclobutanil, flusilazole, and tebuconazole. Chlorothalonil products (e.g., Ortho's Multi-Purpose Fungicide), however, have recently lost their label for home turf use due to the Food Quality Protection Act. Because of the new label, availability of these products has become limited.

Since $D$. rosae survives in fallen leaves, removal and destruction of infected plant debris, done prior to bud break in the spring, should help reduce primary inoculum. However, D. rosae also overwinters in infected canes and buds of the plant $(7,13)$, which would explain increasing disease pressure on roses from year to year, as observed in a previous study (3). We hypothesized that it might be possible to reduce $D$. rosae survival if rose canes were treated with fungicides during plant dormancy. Thus, the objective of this study was to evaluate the effect of winter applications of fungicides on the onset and season-long development of black spot disease on hybrid tea rose plants. Winter applications of the fungicides chlorothalonil (in solution with a latex antitranspirant, VaporGard), triforine, cyproconazole, and myclobutanil were compared with no treatment and with horticultural oil applications.

\section{MATERIALS AND METHODS}

Field plots. Studies were conducted at three sites in two locations: two sites on the Auburn University campus in Auburn, AL, and one at the Horticultural Subunit of the E. V. Smith Research Center, Alabama Agricultural Experiment Station System, near Shorter. Campus rose beds were located approximately $0.5 \mathrm{~km}$ apart, with one in Ross Square and the other in front of Comer Hall. Beds at both campus sites had been planted with roses in years prior to this study. All original rose plants were removed from campus beds, and new plants were established in September 1996. At the Ross Square site, one each of four cultivars, Crystalline, French Perfume, Heaven, and Queen Elizabeth, planted on 1.2-m (4-ft) centers, comprised each treatment plot. Three replications of the four treatments were at the Ross Square site. At the Comer Hall site, one plant of each of three cultivars (Ingrid Bergman, Kordes Perfecta, and Seashell) comprised each of five treatment plots, with three replications of treatments. Plants for these studies were donated by various companies without regard for disease reaction.

At both campus sites, beds were mulched with pine bark during planting and treatments were arranged in a randomized complete block design with cultivars as subplots. Plants were individually side-dressed with $\sim 30 \mathrm{~g}$ of a granular rose fertilizer (Rose Food 20-11-12, Scotts Co., Marysville, $\mathrm{OH}$ ) during the first week of May, July, and September of each growing season.

Studies were started in autumn 1997 on hybrid tea rose plants established in spring 1992 (3) at the Shorter site. Plots consisted of one each of the three hybrid tea rose cultivars, Cary Grant, Princess of Monaco, and Dolly Parton. Treatments were arranged in a randomized complete block design, with cultivars as subplots and three replications. In February 1996, dead plants were replaced. In February to early March 
of each study year, mulch from the prior year was removed and replaced with a fresh $10-\mathrm{cm}$ layer of pine needles. A drip irrigation system was used to supply fertilizer during the growing season with weekly applications of $200 \mathrm{mg} \mathrm{N}$ liter $^{-1}$ from 20-10-20 (Peters General Purpose, Scotts-Sierra, Marysville, $\mathrm{OH}$ ) beginning 1 June, according to standard recommendations (2).

Supplemental water was supplied to all rose plants through overhead irrigation at campus sites and through drip irrigation at the Shorter site. Plants were irrigated whenever weekly rainfall was less than 2.5 $\mathrm{cm}$. Weeds were controlled by hand removal, mowing, or directed applications of glyphosate as needed. All plants were pruned to a uniform height of approximately $30 \mathrm{~cm}$ in late February of each study year. Starting in May of each year, suckers, spent flowers, and diseased canes were pruned at 14-day intervals according to recommendations (2).

Treatments. Fungicide applications during the winter were scheduled based on frost dates and minimum daily temperatures. The initial treatment application was made within 1 week of the first frost (expected mid-November), with subsequent applications made following 30 consecutive days of minimum temperatures higher than $-2.2^{\circ} \mathrm{C}$ and no later than budbreak (usually mid-March). On-campus treatment applications were made 28 October and 28 November 1996, and 8 March 1997; and 7 November 1997 and 2 March 1998. At the Shorter location, winter fungicide applications were made on 21 November 1997 and 19 February 1998, and 20 November 1998 and 15 February 1999.

Products evaluated at both campus sites were: (i) horticultural mineral oil $(1 \%$ vol/vol SunSpray Ultra-Fine Spray Oil, Sun Company, Philadelphia, PA) in water, (ii) chlorothalonil (1.3 g a.i. liter $^{-1}$ as Da-

Table 1. Julian Date (JD) and calendar date of initial observation of black spot disease on hybrid tea roses treated differentially during the winter months at Auburn University

\begin{tabular}{|c|c|c|c|c|c|}
\hline \multirow[b]{2}{*}{ Site } & \multirow[b]{2}{*}{ Treatment } & \multicolumn{2}{|c|}{1997} & \multicolumn{2}{|c|}{1998} \\
\hline & & Onset $(J D)^{y}$ & Date & Onset $(J D)^{y}$ & Date \\
\hline \multirow[t]{4}{*}{ Ross Square } & None & $97 a^{z}$ & 6 April & $84 \mathrm{a}$ & 24 March \\
\hline & Oil solution & $110 \mathrm{a}$ & 19 April & $80 \mathrm{a}$ & 20 March \\
\hline & $\begin{array}{c}\text { Chlorothalonil + } \\
\text { VaporGard }\end{array}$ & $101 \mathrm{a}$ & 10 April & $84 \mathrm{a}$ & 24 March \\
\hline & $\begin{array}{c}\text { Cyproconazole } \\
\text { LSD }\end{array}$ & $\begin{array}{c}115 \mathrm{a} \\
20\end{array}$ & 24 April & $\begin{array}{c}91 b \\
5\end{array}$ & $31 \mathrm{March}$ \\
\hline \multirow[t]{6}{*}{ Comer Hall } & None & $122 \mathrm{ab}$ & 1 May & $84 \mathrm{a}$ & 24 March \\
\hline & Oil solution & $112 \mathrm{a}$ & 21 April & $86 \mathrm{a}$ & 26 March \\
\hline & $\begin{array}{c}\text { Chlorothalonil + } \\
\text { VaporGard }\end{array}$ & $128 \mathrm{ab}$ & 7 May & $95 \mathrm{a}$ & 4 April \\
\hline & Cyproconazole & $147 \mathrm{~b}$ & 26 May & $116 \mathrm{~b}$ & 25 April \\
\hline & Triforine & $126 a b$ & 5 May & $96 \mathrm{a}$ & 5 April \\
\hline & LSD & 26 & & 14 & \\
\hline
\end{tabular}

y JDs in columns are means of four plants per plot with three replications of each treatment plot in the Ross Square bed; in the Comer Hall bed, three plants comprised each plot, and treatment plots were replicated three times.

${ }^{\mathrm{z}}$ Letters following data in column, by site, when different, indicate significant differences according to Fisher's protected least significant difference $(P<0.05)$. to 5 with $0=$ no defoliation, $1=$ up to $20 \%$ of the plant defoliated, $2=20$ to $40 \%$ of the plant defoliated, $3=40$ to $60 \%$ of the plant defoliated, $4=60$ to $80 \%$ of the plant defoliated, and $5=$ more than $80 \%$ of the plant defoliated. Vigor was rated on a scale of 0 to 5 with $0=$ dead plant, $1=$ poorly formed plant with little or no new growth, 2 = poorly formed plant with new growth, $3=$ moderately branched plant with new growth, 4 = well-developed plant with minimal new growth, and $5=$ welldeveloped plant with abundant new growth. Flower production was the sum of buds showing color, blooms, and spent flowers.

Temperature and rainfall data were obtained from weather stations closest to each site. The weather station for Auburn is approximately $1 \mathrm{~km}$ and $1.5 \mathrm{~km}$ from the Comer Hall and Ross Square sites, respectively. The weather station for the Shorter site is located approximately $2 \mathrm{~km}$ from plots.

Data analysis. Dates of initial observation of disease (onset) were recorded as Julian Date (JD). Areas under the disease progress curve (AUDPC) and under the defoliation progress curve (AUDFC) were calculated for each treatment as AUDPC $\left(\right.$ or AUDFC) $=\Sigma\left[(1 / 2)\left(y_{i+1}+y_{i}\right)\left(t_{i+1}-t_{i}\right)\right]$ where $y=$ disease (or defoliation) rating (0 to 5) at time $t$ and $i=$ day of assessment from the first date of assessment (4). Vigor ratings and flower counts were averaged over the season. The significance of treatment and cultivar effects at each site in each year were determined through analysis of variance (ANOVA). Treatment and cultivar means were compared using Fisher's protected least significant difference (LSD) test with significance at $P<$ 0.05 unless otherwise stated.

\section{RESULTS}

At the Auburn campus, November 1996 through March 1997 was warmer with less rain than November 1997 through March 1998 (average of $11.8^{\circ} \mathrm{C}$ with $44.6 \mathrm{~cm}$ of rain versus $9.7^{\circ} \mathrm{C}$ with $74.4 \mathrm{~cm}$ of rain, respectively). Average daily temperatures on-campus for May through September 1998, when disease, defoliation, vigor, and flowers were evaluated, ranged from 16.1 to $30.6^{\circ} \mathrm{C}$ with $42.6 \mathrm{~cm}$ of rain. At the Shorter site, the 1998 growing season was generally warmer than that of 1999 , with daily temperature averages of 26.6 and $25.1^{\circ} \mathrm{C}$, respectively. While rainfall during the 1998 growing season at the Shorter site was less than in 1999 (48.6 cm and 55.35 $\mathrm{cm}$, respectively), both seasons had adequate relative humidity and moisture for black spot development.

Effects of winter fungicide applications on disease onset, Auburn campus sites. Black spot disease onset was earlier in the second year of the study, with onset over both sites occurring on or after JD 97 (6 April) in 1997 compared with JD 80 (20 
March) or later in 1998. Black spot onset on plants treated with the horticultural oil or chlorothalonil at both sites, or with triforine at the Comer Hall site, was statistically similar to date of disease onset on nontreated plants in two study years (Table 1). Disease onset was delayed on plants treated with cyproconazole compared with all other treatments at the two sites and both study years (Table 1). Each of the winter fungicide treatments tended to delay onset, with delays averaging 4.8 days with chlorothalonil application, 8 days with triforine, and 20.2 days with cyproconazole compared with no winter treatment.

Early-season effects of winter fungicide application. Analysis of 31 May 1997 data showed that non-winter-treated plants had greater black spot disease severity than those plants treated with fungicides during the winter (Table 2). At the Ross Square site, each of the winter treatments decreased disease and improved flower production compared with no treatment. At the Comer Hall site in 1997, plants treated with fungicidal winter treatments (chlorothalonil, triforine, or cyproconazole) had lower disease and defoliation, as well as better vigor, than oil-treated or nontreated plants. In 1998 on 25 April at Ross Square, only the cyproconazole treatment reduced disease compared with each of the other winter treatments; no differences were observed in defoliation, vigor, or flowers due to winter treatment. At Comer Hall, plants treated with each of the fungicidal winter treatments had lower disease and defoliation compared with nontreated plants. Plants at the Comer Hall site in 1998 treated during the winter with any fungicide generally had greater vigor and flower production than nontreated plants (Table 2).

Early-season differences due to winter treatment were detected in 1998 and 1999 at the Shorter site. On 30 April 1998, disease and defoliation of rose plants treated with either triforine or cyproconazole during the winter were lower $(P<0.05)$ than on myclobutanil-treated or nontreated plants. Both triforine and cyproconazole winter-treated plants had significantly greater vigor and flower production on 30
April 1998 than nontreated plants (Table $3)$. In 1999, roses had barely broken dormancy by the first assessment date of 5 April. On 14 May 1999, disease and defoliation levels were still very low (ratings less than 1.0) and did not differ significantly among treatments (Table 3). Vigor ratings and flower production did not differ significantly among treatments, but plants treated with fungicides during the winter did tend to have more flowers than nontreated plants (Table 3 ).

Table 3. Ratings of black spot disease, defoliation, vigor, and flower production of hybrid tea roses in early spring of two study years following differential treatment during preceding winter months at the E.V. Smith Research Center, Horticultural Subunit, near Shorter, AL

\begin{tabular}{llcccc}
\hline Date & Treatment & Disease $^{\mathbf{v}, \mathbf{w}}$ & Defoliation $^{\mathbf{w}}$ & Vigor $^{\mathbf{x}}$ & Flowers $^{\mathbf{y}}$ \\
\hline 30 April 1998 & None & $3.4 \mathrm{a}^{\mathrm{z}}$ & $1.5 \mathrm{a}$ & $2.2 \mathrm{~b}$ & $3.1 \mathrm{~b}$ \\
& Myclobutanil & $3.2 \mathrm{a}$ & $1.8 \mathrm{a}$ & $2.6 \mathrm{~b}$ & $5.8 \mathrm{ab}$ \\
& Triforine & $2.8 \mathrm{a}$ & $1.1 \mathrm{ab}$ & $3.7 \mathrm{a}$ & $10.6 \mathrm{a}$ \\
& Cyproconazole & $0.8 \mathrm{~b}$ & $0.5 \mathrm{~b}$ & $3.6 \mathrm{a}$ & $9.8 \mathrm{a}$ \\
14 May 1999 & LSD & 0.9 & 0.7 & 0.9 & 6.0 \\
& None & $0.6 \mathrm{a}$ & $0.0 \mathrm{a}$ & $3.3 \mathrm{a}$ & $4.8 \mathrm{a}$ \\
& Myclobutanil & $0.2 \mathrm{a}$ & $0.0 \mathrm{a}$ & $3.3 \mathrm{a}$ & $7.9 \mathrm{a}$ \\
& Triforine & $1.0 \mathrm{a}$ & $0.0 \mathrm{a}$ & $3.0 \mathrm{a}$ & $6.0 \mathrm{a}$ \\
& Cyproconazole & $0.2 \mathrm{a}$ & $0.0 \mathrm{a}$ & $3.9 \mathrm{a}$ & $8.4 \mathrm{a}$ \\
& LSD & 0.9 & 0.0 & 0.8 & 3.4 \\
\hline
\end{tabular}

${ }^{\mathrm{v}}$ Data in columns are means over three cultivars per plot with three replications of each treatment.

${ }^{\text {w }}$ Disease and defoliation ratings were on a scale from 0 to 5 where $0=$ no disease or defoliation, $1=$ up to $20 \%$ of plant with black spot symptoms or defoliated, $2=20$ to $40 \%$ of foliage with symptoms of black spot or defoliation of plant, $3=40$ to $60 \%$ of foliage with symptoms of black spot or defoliation of plant, $4=60$ to $80 \%$ of foliage with symptoms of black spot or defoliation of plant, and $5=80 \%$ or more of foliage with black spot symptoms or defoliation of plant.

${ }^{\mathrm{x}}$ Data represent average vigor over season. Vigor was rated from 0 to 5 where $0=$ dead plant, $1=$ poorly formed plant with little or no new growth, $2=$ poorly formed plant with new growth, $3=$ moderately branched plant with new growth, 4 = well-developed plant with minimal new growth, and $5=$ well-developed plant with abundant new growth

${ }^{y}$ Data represent average flower production over season, enumerated every 14 days.

${ }^{\mathrm{z}}$ Letters following data in column, by site, when different, indicate significant differences according to Fisher's protected least significant difference $(P<0.05)$.

Table 2. Early-season ratings of black spot disease, defoliation, vigor, and flower production of hybrid tea roses in early spring of two study years after differential treatment during preceding winter months at two Auburn University campus sites, 31 May 1997 and 25 April 1998

\begin{tabular}{|c|c|c|c|c|c|c|c|c|c|}
\hline \multirow[b]{2}{*}{ Site } & \multirow[b]{2}{*}{ Treatment } & \multicolumn{4}{|c|}{1997} & \multicolumn{4}{|c|}{1998} \\
\hline & & Disease $^{v, w}$ & Defol.w & Vigor $^{x}$ & Flowers $^{y}$ & Disease $^{w}$ & Defol.w & Vigor $^{x}$ & Flowers \\
\hline \multirow[t]{5}{*}{ Ross Square } & None & $2.7 \mathrm{a}^{\mathrm{z}}$ & $1.9 \mathrm{a}$ & $2.2 \mathrm{a}$ & $4.8 \mathrm{c}$ & $2.3 \mathrm{a}$ & $0.9 \mathrm{~b}$ & $3.5 \mathrm{~b}$ & $3.9 \mathrm{a}$ \\
\hline & Oil solution & $1.4 \mathrm{~b}$ & $1.2 \mathrm{a}$ & $2.3 \mathrm{a}$ & $16.8 \mathrm{a}$ & $2.7 \mathrm{a}$ & $0.7 \mathrm{~b}$ & $3.8 \mathrm{ab}$ & $3.8 \mathrm{a}$ \\
\hline & $\begin{array}{c}\text { Chlorothalonil + } \\
\text { VaporGard }\end{array}$ & $1.7 \mathrm{~b}$ & $1.7 \mathrm{a}$ & $2.2 \mathrm{a}$ & $12.9 \mathrm{~b}$ & $2.5 \mathrm{a}$ & $0.7 \mathrm{~b}$ & $3.8 \mathrm{ab}$ & $4.1 \mathrm{a}$ \\
\hline & Cyproconazole & $1.2 \mathrm{~b}$ & $1.1 \mathrm{a}$ & $2.2 \mathrm{a}$ & $9.5 \mathrm{~b}$ & $1.1 \mathrm{~b}$ & $0.0 \mathrm{a}$ & $4.4 \mathrm{a}$ & $2.1 \mathrm{a}$ \\
\hline & LSD & 0.6 & 0.8 & 0.2 & 3.6 & 0.7 & 0.7 & 0.6 & 3.1 \\
\hline \multirow[t]{6}{*}{ Comer Hall } & None & $2.9 \mathrm{a}$ & $2.8 \mathrm{a}$ & $1.9 \mathrm{~b}$ & $7.7 \mathrm{a}$ & $2.6 \mathrm{a}$ & $1.3 \mathrm{a}$ & $3.3 \mathrm{~b}$ & $0.2 \mathrm{~b}$ \\
\hline & Oil solution & $3.1 \mathrm{a}$ & $2.3 \mathrm{a}$ & $2.1 \mathrm{~b}$ & $4.9 \mathrm{a}$ & $2.0 \mathrm{ab}$ & $0.8 \mathrm{ab}$ & $3.1 \mathrm{~b}$ & $0.3 \mathrm{~b}$ \\
\hline & $\begin{array}{c}\text { Chlorothalonil + } \\
\text { VaporGard }\end{array}$ & $1.6 \mathrm{~b}$ & $1.0 \mathrm{~b}$ & $2.6 \mathrm{a}$ & $8.5 \mathrm{a}$ & $1.2 \mathrm{~b}$ & $0.2 \mathrm{~b}$ & $3.3 \mathrm{~b}$ & $1.2 \mathrm{a}$ \\
\hline & Cyproconazole & $0.6 \mathrm{c}$ & $0.5 \mathrm{~b}$ & $2.7 \mathrm{a}$ & $8.8 \mathrm{a}$ & $0.3 \mathrm{c}$ & $0.2 \mathrm{~b}$ & $4.4 \mathrm{a}$ & $0.4 \mathrm{a}$ \\
\hline & Triforine & $2.0 \mathrm{~b}$ & $1.3 \mathrm{~b}$ & $2.6 \mathrm{a}$ & $8.2 \mathrm{a}$ & $1.6 \mathrm{~b}$ & $0.2 \mathrm{~b}$ & $4.4 \mathrm{a}$ & $0.7 \mathrm{ab}$ \\
\hline & LSD & 0.6 & 1.0 & 0.5 & 6.4 & 0.9 & 0.7 & 0.7 & 0.7 \\
\hline
\end{tabular}

${ }^{v}$ Data in columns are means over three plants per plot with three replications of each treatment plot at the Ross Square site; at the Comer Hall site, three plants comprised each plot, and treatment plots were replicated three times.

${ }^{w}$ Disease and defoliation ratings were on a scale from 0 to 5 where $0=$ no disease or defoliation, $1=$ up to $20 \%$ of plant with black spot symptoms or defoliated, $2=20$ to $40 \%$ of foliage with symptoms of black spot or defoliation of plant, $3=40$ to $60 \%$ of foliage with symptoms of black spot or defoliation of plant, $4=60$ to $80 \%$ of foliage with symptoms of black spot or defoliation of plant, and $5=80 \%$ or more of foliage with black spot symptoms or defoliation of plant.

${ }^{\mathrm{x}}$ Data represent average vigor over season. Vigor was rated from 0 to 5 where $0=$ dead plant, $1=$ poorly formed plant with little or no new growth, $2=$ poorly formed plant with new growth, $3=$ moderately branched plant with new growth, $4=$ well-developed plant with minimal new growth, and $5=$ well-developed plant with abundant new growth.

${ }^{\mathrm{y}}$ Data represent average flower production over season, enumerated every 14 days.

${ }^{\mathrm{z}}$ Letters following means in column, by site, when different, indicate significant differences according to Fisher's protected least significant difference ( $P$ $<0.05)$. 
1998 season-long effects at Auburn campus sites. Each of the assessed parameters varied through the growing season. For example, flower production peaked in early May at the Ross Square site on all plants regardless of treatment (Fig. 1). Disease levels among treatments became similar by early June at the Ross Square site, but defoliation of rose plants treated with cyproconazole or chlorothalonil remained lower than oil-treated or
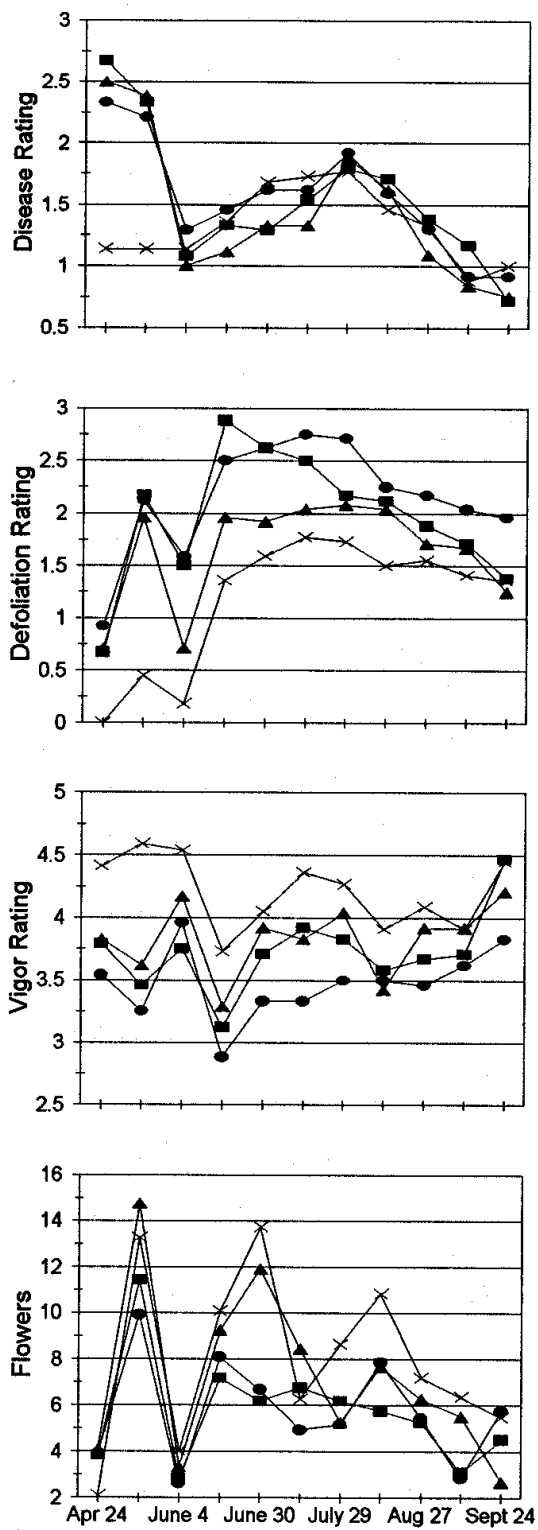

Fig. 1. Ratings of disease and defoliation due to black spot disease, and vigor ratings and flowering of hybrid tea rose plants at the Ross Square site through the 1998 growing season. Differential treatments were applied November 1997 through March 1998; uniform fungicide treatments were applied 1 May through 1 October. Solid lines with circular $(\bullet)$ marker represent no winter treatment, with square (ם) marker represent oil treatment, with triangular (A) marker represent chlorothalonil treatment, and with $(x)$ marker represent cyproconazole treatment. nontreated plants through the growing season (Fig. 1).

In 1998 at the Ross Square site, AUDFC, vigor, and flower production were significantly affected by winter treatment, and cultivar significantly affected all four measured parameters (Table 4). At the Comer Hall site in 1998, there were significant effects due to winter
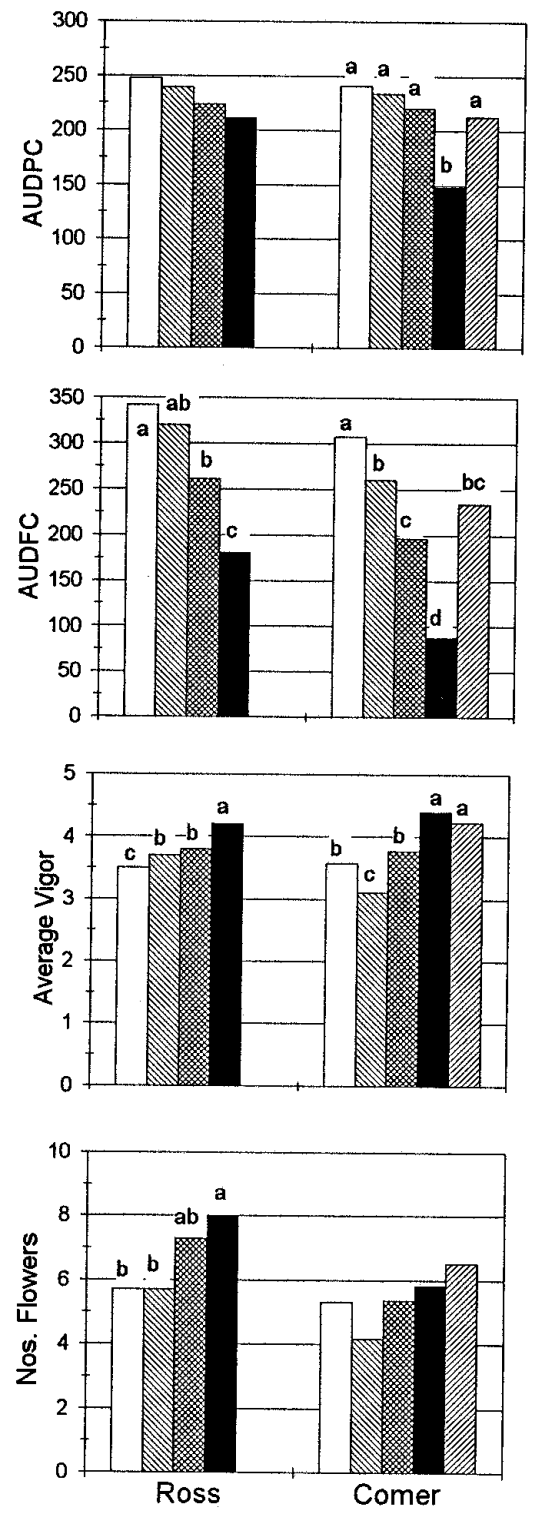

$\square$ None chloro cypro Triforine

Fig. 2. Areas under progress curves for disease and defoliation ratings, and average vigor and flower production of hybrid tea rose plants (1 May through 1 October 1998). Roses were grown in beds on the Auburn University campus. Differential treatments were applied November 1997 through March 1998; uniform fungicide treatments were applied 1 May through 1 October. Letters on bars, when different, indicate significance differences among treatments, according to LSD analysis $(P<$ $0.05)$. treatment on AUDPC, AUDFC, and vigor, while cultivar significantly affected vigor and flower production. Analysis of variance of season-long data indicated that there were no significant effects $(P<0.05)$ due to winter treatment*cultivar (2-way) interaction on AUDPC, AUDFC, vigor, or flower numbers at either campus site. At the Comer Hall site, one of the replications was inadequately irrigated, and this probably explains the significant replication effect (Table 4).

At the Comer Hall site, cyproconazole applied during the winter resulted in the lowest AUDPC over the subsequent growing season compared with each of the other winter treatments and the nontreated controls (Fig. 2). At both campus sites,
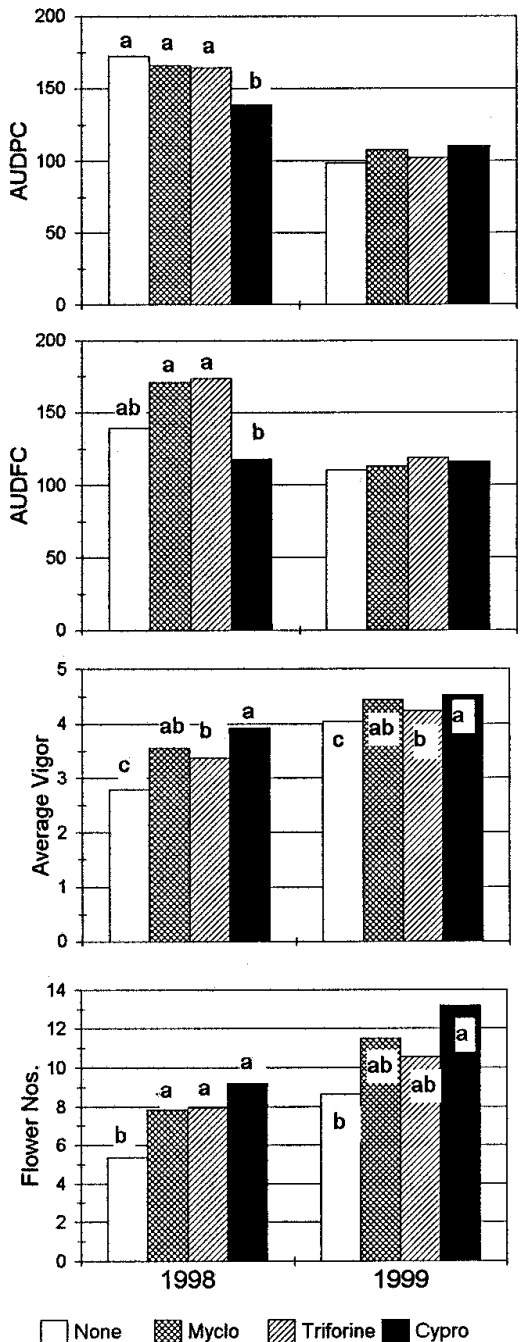

Fig. 3. Areas under progress curves for disease and defoliation ratings, and average vigor and flower production of hybrid tea rose plants near Shorter, AL, for the 1998 and 1999 growing seasons. Differential treatments were applied November through March preceding each growing season. Letters on bars, when different, indicate significant differences among treatments according to LSD analysis $(P<$ $0.05)$. 
AUDFC tended to be lower with any of the winter treatments compared with no treatment. Season-long vigor was consistently greater on plants treated with chlorothalonil, cyproconazole or triforine, during the winter compared with no treatment or the oil treatment at both campus sites (Fig. 2). Average flower production over the growing season tended to be greater on plants treated with either systemic fungicide, cyproconazole, or triforine during the preceding winter at both campus sites compared with the oil, chlorothalonil, or no winter treatments (Fig. 2).

Season-long effects due to winter treatments, Shorter site. AUDPC and AUDFC over the 1998 growing season were significantly affected by winter treatment according to LSD analysis $(P<$ 0.05). Cultivar and the 2-way interaction of winter treatment*cultivar also significantly affected AUDPC, but not AUDFC. Average vigor and flower production in 1998 were affected by winter treatment and cultivar, but not by the winter treatment*cultivar interaction. In 1999, there were no significant effects on AUDPC or AUDFC due to winter treatment, cultivar, or the 2-way interaction of these factors. Vigor and flower production over the 1999 growing season were significantly affected by winter treatment and cultivar, but not by the 2-way interaction of winter treatment*cultivar.

Over all three cultivars, plants treated with cyproconazole had a lower AUDPC in 1998 than plants treated otherwise, and this trend was consistent for Cary Grant and Dolly Parton (data not shown). However, AUDPC was lowest following the myclobutanil winter treatment on Princess of Monaco, and this accounts for the significance of the 2-way interaction on AUDPC. AUDFC was consistently lower on plants treated with cyproconazole than on plants treated with myclobutanil or triforine in 1998 (Fig. 3). AUDPC and AUDFC were 40 and $28 \%$ lower, respectively, in 1999 than in the preceding year, and neither of these parameters were affected by winter treatment in 1999. In both study years, each of the winter fungicide treatments tended to improve vigor and flower production through the growing season compared with no winter treatment (Fig. 3).

Cultivar effects. Among the four cultivars at Ross Square in 1998, Queen Elizabeth had lower disease and defoliation, and greater vigor than the other cultivars (Table 5). Crystalline and Queen Elizabeth had better vigor than French Perfume or Heaven; Crystalline also had the greatest flower production among cultivars at Ross Square. AUDPC and AUDFC did not differ among cultivars at the Comer Hall; however, Ingrid Bergman consistently had greater vigor and more flowers than Kordes Perfecta and Seashell. At the Shorter site, Cary Grant and Princess of
Monaco had lower AUDPCs than Dolly Parton, although defoliation of these cultivars was similar. Cary Grant had better vigor and greater flower production than the other two cultivars at the Shorter site in 1998 (Table 5).

\section{DISCUSSION}

The application of lime-sulfur fungicidal products to rose canes prior to bud break is a recommended disease control practice $(2,8)$. Regular preventative applications of fungicides to rose plants during the growing season to control black spot have also long been recommended. Weekly applications of myclobutanil, tebuconazole, and flusilazole have proven superior for black spot disease control compared with applications made on 14-day intervals (11).
However, fewer fungicide applications over a growing season, without a loss in disease control, is desirable. Products with longer efficacy against diseases of rose are continually sought and tested $(5,14,15)$; however, there are no indications that improvements on the dormant lime-sulfur application are being sought. This study was designed to evaluate the effect of fungicide applications to hybrid tea rose canes, during the winter, on black spot disease onset and development.

Venturia inaequalis, the causal organism of apple scab, is similar to $D$. rosae in that it overwinters in buds of host plants $(1,7)$. In studies in the northeastern United States, applications of fungicides to apple trees in autumn at the time of leaf fall have been observed to reduce the development

Table 4. Analyses of variance of areas under the disease progress curve for black spot (AUDPC) and defoliation progress curve (AUDFC), average vigor, and flower production on hybrid tea roses from May through September 1998 at Auburn campus sites ${ }^{\mathrm{x}}$

\begin{tabular}{lrcclc}
\hline & & \multicolumn{4}{c}{ Mean squares $^{\mathbf{y}}$} \\
\cline { 4 - 6 } Site and factor & df & AUDPC & AUDFC & Vigor & Flower \\
\hline Ross Square & 48 & & & & \\
Rep & 2 & 653 & 708 & 0.27 & 2.01 \\
Treatment & 3 & 3,014 & $59,495^{* z}$ & $1.14^{*}$ & $15.21^{*}$ \\
Error A & 6 & 2,082 & 7,094 & 1.13 & 7.48 \\
Cultivar & 3 & $6,502^{*}$ & $49,504^{*}$ & $5.38^{*}$ & $47.39^{*}$ \\
Cultivar*trt & 9 & 1,694 & 5,813 & 0.08 & 6.66 \\
Error B & 24 & 1,456 & 5,999 & 0.16 & 3.70 \\
Comer Hall & 44 & & & & \\
Rep & 2 & 5,983 & $6,536^{*}$ & $7.5^{*}$ & $144.0^{*}$ \\
Treatment & 4 & $12,190^{*}$ & $61,971^{*}$ & $2.4^{*}$ & 6.8 \\
Error A & 8 & 2,820 & 5,065 & 0.5 & 3.1 \\
Cultivar & 2 & 5,995 & 5,411 & $1.0^{*}$ & $20.1^{*}$ \\
Cultivar*trt & 8 & 3,091 & 2,976 & 0.3 & 3.6 \\
Error B & 20 & 2,196 & 1,716 & 0.2 & 2.7 \\
\hline
\end{tabular}

${ }^{\mathrm{x}}$ Data are from rose plants treated during the preceding winter with different fungicides.

${ }^{y}$ Data were analyzed according to a split-plot arrangement with winter treatments as main plots and cultivars as subplots.

${ }^{\mathrm{z}}$ Asterisk indicates a significant effect at the 0.05 level of probability.

Table 5. Areas under disease and defoliation progress curves (AUDPC and AUDFC, respectively) for black spot, and average vigor and flower production on hybrid tea rose cultivars at three sites for the 1998 growing season

\begin{tabular}{llcccc}
\hline Site & Cultivar & AUDPC & AUDFC $^{\mathbf{w}}$ & Vigor $^{\mathbf{w}, \mathbf{x}}$ & Flowers $^{\mathbf{w}, \mathbf{y}}$ \\
\hline Ross Square & French Perfume & $261.5 \mathrm{a}^{\mathbf{z}}$ & $282.4 \mathrm{a}$ & $3.3 \mathrm{c}$ & $5.6 \mathrm{~b}$ \\
& Heaven & $234.2 \mathrm{ab}$ & $349.6 \mathrm{a}$ & $3.3 \mathrm{c}$ & $5.2 \mathrm{~b}$ \\
& Crystalline & $217.2 \mathrm{~b}$ & $287.8 \mathrm{a}$ & $3.8 \mathrm{~b}$ & $9.5 \mathrm{a}$ \\
& Queen Elizabeth & $209.5 \mathrm{~b}$ & $193.0 \mathrm{~b}$ & $4.7 \mathrm{a}$ & $6.5 \mathrm{~b}$ \\
\multirow{5}{*}{ Comer Hall } & LSD & 34.2 & 71.1 & 0.4 & 1.8 \\
& Ingrid Bergman & $194.4 \mathrm{a}$ & $226.8 \mathrm{a}$ & $4.1 \mathrm{a}$ & $6.3 \mathrm{a}$ \\
& Kordes Perfecta & $209.2 \mathrm{a}$ & $196.8 \mathrm{a}$ & $3.6 \mathrm{~b}$ & $4.2 \mathrm{~b}$ \\
& Seashell & $230.7 \mathrm{a}$ & $230.0 \mathrm{a}$ & $3.8 \mathrm{~b}$ & $5.8 \mathrm{a}$ \\
\multirow{5}{*}{ Shorter } & LSD & 36.5 & 35.2 & 0.3 & 1.2 \\
& Cary Grant & $136.6 \mathrm{~b}$ & $145.4 \mathrm{a}$ & $3.7 \mathrm{a}$ & $8.7 \mathrm{a}$ \\
& Dolly Parton & $194.1 \mathrm{a}$ & $140.5 \mathrm{a}$ & $3.5 \mathrm{a}$ & $7.0 \mathrm{~b}$ \\
& Princess of Monaco & $149.0 \mathrm{~b}$ & $167.6 \mathrm{a}$ & $2.9 \mathrm{~b}$ & $6.9 \mathrm{~b}$ \\
& $\quad$ LSD & 20.1 & 36.7 & 0.4 & 1.4
\end{tabular}

${ }^{\text {w }}$ Data are means over four treatments at Ross Square, five treatments at Comer Hall, and four treatments at the Shorter site, and three replications of each treatment.

${ }^{\mathrm{x}}$ Data represent average vigor over season. Vigor was rated from 0 to 5 where $0=$ dead plant, $1=$ poorly formed plant with little or no new growth, 2 = poorly formed plant with new growth, $3=$ moderately branched plant with new growth, $4=$ well-developed plant with minimal new growth, and $5=$ well-developed plant with abundant new growth.

${ }^{y}$ Data represent average flower production over season, enumerated every 14 days.

${ }^{\mathrm{z}}$ Letters following data in column, by site, when different, indicate significant differences according to Fisher's protected least significance difference $(P<0.05)$. 
of overwintering structures of $V$. inaequalis (9). These late autumn fungicide applications subsequently allowed delayed initiation of fungicide applications in the following spring without a loss of disease control (9).

Delaying the start of fungicide applications in the spring of the year could decrease the total number of fungicide applications in a growing season. While we did not specifically evaluate the efficacy of delaying fungicide applications in the spring following winter treatments, disease levels were generally lower and vigor tended to be greater at the time of our first assessments (April and May) on wintertreated plants (Tables 2 and 3). Our first assessments in 1998 and 1999 were done prior to initiation of a regular fungicide program through the growing season, indicating that winter treatments can reduce disease severity and fungicide use during the early weeks of a growing season. In addition, since bud break of rose plants generally occurs in late March to early April in our conditions, and bud break is the recommended time for initiation of a fungicide program for control of black spot on roses (6), the start of our fungicide program was delayed compared with recommendations. Additional studies are needed that specifically address an integration of winter treatment with delayed initiation of a fungicide program for the growing season.

Gadoury and his co-workers (9) observed that various fungicidal products applied in late autumn had differential efficacy in reducing ascospore production in the subsequent spring. Among the fungicides they evaluated, autumn applications of the systemic fungicides myclobutanil and triforine were more effective than the protectant fungicide chlorothalonil in reducing ascospore production (9). These results are similar to our observations at campus sites in that the systemic fungicides triforine and cyproconazole, when applied to rose plants in winter, delayed onset of black spot more than did chlorothalonil (Table 1). While each of these fungicidal winter treatments reduced season-long disease and defoliation due to black spot, the two systemic fungicides triforine and cyproconazole improved average vigor better than did chlorothalonil at campus sites in 1998.

Our results indicate that systemic fungicides, applied two or three times during winter months, can improve the health of rose plants in the southeastern landscape throughout the subsequent growing season. Results from 1998 and 1999 at the Shorter site demonstrated that both myclobutanil and triforine winter treatments improved season-long vigor and flower production compared with nontreated plants. Winter applications of the EBI fungicide cyproconazole reduced disease and defoliation better than other tested fungicides. However, this product is not available for use. The superior efficacy of this particular EBI fungicide does, however, indicate that additional products need to be tested for efficacy as winter treatments in managing rose plant health.

In studies on apple scab in the northeastern United States, a single "postharvest" fungicide application was applied to reduce ascospore production of $V$. inaequalis the following spring (9). In the southeastern United States, where temperatures are more moderate from November through March than in the northeastern United States, multiple winter applications of fungicides may be necessary. We made our initial winter treatment application within 1 week of the first frost date, then reapplied treatments when 30 days had occurred with temperatures higher than $-2.2^{\circ} \mathrm{C}$. This application schedule was based on observations that rose plants will break dormancy in these conditions (30 days $>-2.2^{\circ} \mathrm{C}$ ). However, such precision in scheduling winter fungicide applications may not be needed, particularly with systemic fungicides. Flexibility in scheduling systemic fungicide applications that contribute to early-season disease control would be desirable from a management perspective. Further tests are needed to determine precisely how many winter treatments or what application schedule may be needed for the most efficient black spot management in the southeastern United States.

In studies at the Shorter site, the three systemic fungicides, cyproconazole, myclobutanil, and triforine, applied during the winter, did not consistently reduce seasonlong disease or defoliation over each of the two study years. Each of these fungicides, however, did consistently improve seasonlong vigor and flower production compared with no winter treatment. In a previous study, rose plant vigor and flower production were found to be negatively correlated to AUDPC (3). Similarly, in the current studies, we observed that the cultivar with the lowest AUDPC at each site consistently had greater vigor and flower production than other cultivars at that site (Table 5). Thus, the increase in plant vigor was probably due to the delay in disease onset and reductions in early-season disease levels following winter treatments.

Each of the hybrid tea rose plants were uniformly treated during the growing sea- sons with chlorothalonil on 2-week intervals. By mid-June, after 6 weeks of similar chlorothalonil applications, and more than 12 weeks following the winter treatments, disease levels were similar among all plots, including nontreated plots (Fig. 1). This would be expected with a polycyclic disease such as black spot. With a delay in disease onset, lower areas under disease progress curves would also be expected (4). However, plants with delayed disease onset following winter treatments also had greater plant vigor through the subsequent growing season. Improved vigor of plants through the growing season with fungicidal winter treatments emphasizes the importance of early-season disease management on roses.

\section{LITERATURE CITED}

1. Becker, C. M., Burr, T. J., and Smith, C. A. 1992. Overwintering of conidia of Venturia inaequalis in apple buds in New York orchards. Plant Dis. 76:121-126.

2. Behe, B. K., Williams, J. D., Cobb, P., Hagan, A. K., and Stritikus, G. 1993. Growing roses. Ala. Coop. Ext. Serv. Circ. ANR-157.

3. Bowen, K. L., Young, B., and Behe, B. K. 1995. Management of blackspot of rose in the landscape in Alabama. Plant Dis. 79:250-253.

4. Campbell, C. L., and Madden, L. V. 1990 Introduction to Plant Disease Epidemiology. John Wiley \& Sons, New York.

5. Clement, D. L., and Steward, B. V. 1999. Evaluation of a systemic fungicide treatment for control of black spot on roses, 1998. Fungic. Nematicide Tests 54:550.

6. Cobb, P. P., and Hagan, A. K. 1996. Disease and insect control for roses. Ala. Coop. Ext. Serv. Circ. ANR-401.

7. Cook, R. T. A. 1981. Overwintering of Diplocarpon rosae at Wisley. Trans. Br. Mycol. Soc. 77:549-556.

8. Craft, D. 1999. What is Black spot? The American Rose Society. On-line publication.

9. Gadoury, D. M., MacHardy, W. E., and Rosenberger, D. A. 1989. Integration of pesticide application schedules for disease and insect control in apple orchards of the northeastern United States. Plant Dis. 73:98-105.

10. Hagan, A. K., Gilliam, C. H., and Fare, D. C. 1988. Evaluation of new fungicides for control of rose black spot. J. Environ. Hortic. 6:67-69.

11. Hagan, A. K., Gilliam, C. H., Fare, D. C., and Bowen, K. 1991. Application rates and spray schedules of ergosterol-biosynthesis inhibitor fungicides for control of black spot of rose. Plant Dis. 75:1143-1146.

12. Horst, R. K., ed. 1983. Compendium of Rose Diseases. American Phytopathological Society, St. Paul, MN.

13. Lyle, E. W. 1943. Black spot on rose canes. Am. Rose Ann. 28:155-156.

14. McGovern, R. J. 1998. Evaluation of fungicides for control of powdery mildew and black spot in rose, 1997. Fungic. Nematicide Tests 53:487.

15. Pscheidt, J. W., and Wittig, H. P. P. 1997. Efficacy of fungicides for control of black spot and rust of rose, 1996. Fungic. Nematicide Tests 52:410. 